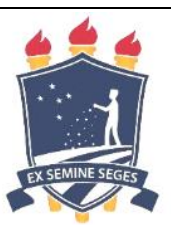

\title{
Wheat middling in diets supplemented with phytase for silver catfish juveniles
}

\author{
[Triguilho em dietas suplementadas com fitase para o jundiá]
}

\section{"Artigo Científico/Scientific Article"}

\author{
Jhonis Ernzen Pessini ${ }^{1 *}$, Milena Souza Santos Sanchez ${ }^{2}$, Mariana Lins Rodrigues ${ }^{2}$, \\ Wilson Rogério Boscolo ${ }^{2}$, Fábio Bittencourt ${ }^{2}$, Altevir Signor ${ }^{2}$
}

\author{
${ }^{1}$ Department of Aquaculture, Federal University of Santa Catarina, Florianópolis-SC, Brazil. \\ ${ }^{2}$ Western Paraná State University, Toledo-PR, Brazil. \\ *Autor para correspondência/Corresponding author: E-mail: jhonispessini@ hotmail.com
}

\begin{abstract}
This study evaluated the use of wheat middling as a replacement for corn in diets supplemented or not with phytase, used to feed Rhamdia quelen silver catfish juveniles. A total of 288 juveniles were used and randomly distributed in 24 aquariums. Data were analyzed by factorial variance and, when significant, means were analyzed with the Tukey's test. Fish were fed four times daily until apparent satiety over the course of 45 days. The results of zootechnical performance showed that diet composition influenced the fat-somatic index with the $100 \%$ substitution level showing the lowest indexes. Fish fed with $100 \%$ wheat middling without phytase had the lowest chemical composition values of ethereal extracts in carcasses. Fish fed with phytase and $100 \%$ wheat middling had the lowest values of calcium and manganese in bone mineral composition. Intestinal histology analysis showed differences in villus height and villi total height in fish fed with the $67 \%$ replacement diet without phytase. The number of goblet cells was not statistically significant. It was concluded that wheat middling, supplemented or not with phytase, can effectively substitute corn in silver catfish diets without losses to productive performance, carcass chemical composition, bone mineral composition, and intestinal morphology.
\end{abstract}

Keywords: alternative feed; aquaculture; catfish; enzyme; substitution.

\section{Resumo}

Este estudo avaliou a utilização do triguilho como um substituto ao milho em dietas, suplementadas ou não com fitase, para juvenis de jundiás (Rhamdia quelen). Foram utilizados 288 juvenis distribuídos aleatoriamente em 24 aquários. Os dados obtidos foram submetidos à análise de variância fatorial e quando significativas, as médias foram submetidas ao teste de Tukey. Para o desempenho zootécnico, houve influência do alimento no índice de gordura víscero-somática, em que o nível de $100 \%$ de substituição apresentou os menores índices. Para a composição química da carcaça, os peixes alimentados com $100 \%$ de triguilho, sem fitase, apresentaram os menores valores de extrato etéreo na carcaça. Na composição mineral óssea, o nível de $100 \%$ de substituição, suplementada com a enzima, apresentou os menores valores de cálcio e manganês. Na análise histológica intestinal, diferenças foram observadas nos peixes alimentados com a dieta com $67 \%$ de substituição do milho pelo triguilho, sem fitase, para altura do vilo e altura total dos vilos. O número de células caliciformes não apresentou diferenças. Conclui-se que o triguilho, independentemente da suplementação enzimática, pode substituir o milho integralmente em dietas para o jundiá sem que ocorram prejuízos sobre o desempenho produtivo, composição química da carcaça, composição mineral óssea e morfologia intestinal.

Palavras-chave: alimento alternativo; aquicultura; catfish; enzima; substituição.

\section{Introdução}

The considerable increase in fish farming in the recent years has attracted the attention of

research focused on lowering production costs and reducing environmental impacts caused by this 
activity (Moutinho et al., 2017). Feed represents the most costly portion of intensive fish culture, easily exceeding $70 \%$ of the total cost. Thus, studies involving substitution with alternative ingredients with lower prices and good quality are of paramount importance to reducing production costs associated with aquatic organisms. Wheat middling, a low cost, good quality byproduct of wheat, is an attractive alternative ingredient, which has been tested in fish diets to replace ingredients such as corn (Hilton and Slinger, 1983; Hughes, 1990; Signor et al., 2007). However, use of plant ingredients can be compromised because their composition includes anti-nutritional factors such as phytate, gossypol, and tannin which reduce nutrient absorption (Francis et al., 2001).

Phytate (phytic acid; myo-inositol hexaphosphate) is an anti-nutritional factor in plants, which binds to phosphorus (Kumar et al., 2012). In addition, it chelates metal ions, proteins, carbohydrates, and lipids, effectively reducing their availability (Vohra and Satyanarayan, 2002). Monogastric animals do not have the capacity to synthesize phytase, the enzyme that hydrolyzes this anti-nutrient (Lelis et al., 2010).

Phytase has the ability to dephosphorylate phytate, producing free inorganic phosphates and lower chain inositol molecules, reducing phytate's chelating capacity (Kumar et al., 2012). Silver catfish, a species belonging to the genus Rhamdia, has triggered interest in researchers and fish farming producers due to its breeding capacity in cold regions (Pedron et al., 2008) and good characteristics for cultivation. Hence, the objective of this study was to determine the effects of using wheat middling as a substitute for corn in phytasesupplemented diets for Rhamdia quelen silver catfish juveniles.

\section{Material and Methods}

\section{Animals and experimental design}

The experiment was conducted over the course of 45 days and used a total of 288 fish with a mean weight of $12.78 \pm 2.78$ grams. Fish were distributed in $24 \times 500 \mathrm{~L}$ cylindrical tanks with a tapered conical bottom equipped with a water recirculation system and constant aeration through a central air blower.

The experimental design was a $4 \times 2$ randomized factorial with four concentrations of wheat middling and two concentrations of phytase supplementation (Table 1); these eight treatments included three replicates and totaled 24 experimental units. Each experimental unit was composed of 12 fish.

\section{Experimental diets}

The ingredients used were individually milled in a $0.5 \mathrm{~mm}$ diameter sieve hammer type crusher, weighed, hand mixed, and extruded in the Ex-Micro® extruder. They were subsequently dried in a forced ventilation oven at $55^{\circ} \mathrm{C}$ for 24 hours and, after cooling, conditioned in plastic bags and stored at $-20^{\circ} \mathrm{C}$. The phytase used in the study (BASF-10,000 FTU/g) was produced by Aspergillus niger and added as granules to the supplemented diets in the amount of 1,500 FTU/kg as indicated by Rocha et al. (2008).

\section{Experimental procedure and sampling methodology}

The fish were fed four times a day $(8: 00 \mathrm{~h}$ and $11: 00 \mathrm{~h} \mathrm{am}$, and $2: 00 \mathrm{~h}$ and $5: 00 \mathrm{~h} \mathrm{pm}$ ) to apparent satiation. After the 45-day experimental period, the fish underwent a 24 -hour fasting period to empty the gastrointestinal tract and were subsequently desensitized with $100 \mathrm{mg} . \mathrm{L}^{-1}$ benzocaine (Gomes et al., 2001) for individual weight measurement $(\mathrm{g})$. After measurements, the fish were euthanized with benzocaine at the dose of $250 \mathrm{mg} . \mathrm{L}^{-1}$ (Gomes et al., 2001). Three fish per replicate were randomly selected for intestine, liver, and visceral-somatic fat removal. Mineral matter was measured in the bones; carcass chemical composition was evaluated in the remaining material.

\section{Zootechnical performance}

The parameters of fish performance were calculated based on weight and amount of feed consumed as: weight gain $(\mathrm{WG}, \mathrm{g})=$ final weight (g) - initial weight (g); specific growth rate (SGR, $\%)=100 \times$ [ln final weight $(\mathrm{g})-\ln$ initial weight (g)]/experimental period; apparent feed conversion $(\mathrm{AFC})=$ supplied feed $(\mathrm{g}) /$ weight gain $(\mathrm{g})$; protein efficiency rate $(\mathrm{PER}, \%)=100 \mathrm{x}$ weight gain $(\mathrm{g}) /$ consumed crude protein $(\mathrm{g})$; hepatosomatic index $(\mathrm{HI}, \%)=100 \mathrm{x}$ liver weight $(\mathrm{g}) /$ final body weight (g); visceral-somatic fat index (VSFI, \%) = $100 \mathrm{x}$ weight of visceral-somatic fat ( $\mathrm{g}$ )/final body weight $(\mathrm{g})$; and survival (SUR, \%) $=100 \mathrm{x}$ final number of fish/initial number of fish.

\section{Analysis of the carcass chemical composition}

The chemical composition of diets and carcasses was analyzed in three fish per replicate. 
The samples were separated and stored at $-20^{\circ} \mathrm{C}$, subsequently pre-dried in an oven at $55^{\circ} \mathrm{C}$ for 72 hours, and analyzed according to the methodology described by AOAC (2000). Analyses included: moisture through drying at $105^{\circ} \mathrm{C}$ for eight hours; crude protein by the Kjeldhal method; lipids by the Soxhlet extractor using ether as the solvent; mineral matter by calcination at $550^{\circ} \mathrm{C}$ for six hours; and rations' energy by means of a calorimetric pump (IKA Basic, 2000).

Table 1. Chemical composition of experimental diets offered to Rhamdia quelen silver catfish juveniles.

\begin{tabular}{|c|c|c|c|c|c|c|c|c|}
\hline \multirow{4}{*}{ Ingredients (\%) } & \multicolumn{8}{|c|}{ Levels of wheat middling substituting corn (\%) } \\
\hline & $\mathbf{0}$ & 33 & 67 & 100 & $\mathbf{0}$ & 33 & 67 & 100 \\
\hline & \multicolumn{8}{|c|}{ Phytase supplementation $(1,500$ FTU/kg) } \\
\hline & $\mathbf{A}^{7}$ & $\mathbf{A}$ & A & A & $\mathbf{P}^{8}$ & $\mathbf{P}$ & $\mathbf{P}$ & $\mathbf{P}$ \\
\hline Fish, meal & 22.00 & 22.00 & 22.00 & 22.00 & 22.00 & 22.00 & 22.00 & 22.00 \\
\hline Soybean meal & 38.81 & 36.65 & 34.49 & 32.33 & 38.81 & 36.65 & 34.49 & 32.33 \\
\hline Corn, grain ${ }^{1}$ & 35.35 & 23.57 & 11.78 & 0.00 & 35.35 & 23.57 & 11.78 & 0.00 \\
\hline Wheat middling ${ }^{2}$ & 0.00 & 14.42 & 28.84 & 43.26 & 0.00 & 14.42 & 28.84 & 43.26 \\
\hline Soy oil & 1.40 & 0.95 & 0.49 & 0.04 & 1.40 & 0.95 & 0.49 & 0.04 \\
\hline Premix $^{3}$ & 1.00 & 1.00 & 1.00 & 1.00 & 1.00 & 1.00 & 1.00 & 1.00 \\
\hline L-threonine & 0.37 & 0.39 & 0.40 & 0.42 & 0.37 & 0.39 & 0.4 & 0.42 \\
\hline DL-methionine & 0.28 & 0.28 & 0.27 & 0.27 & 0.28 & 0.28 & 0.27 & 0.27 \\
\hline Choline chloride & 0.10 & 0.10 & 0.10 & 0.10 & 0.10 & 0.10 & 0.10 & 0.10 \\
\hline Vitamin $C^{4}$ & 0.10 & 0.10 & 0.10 & 0.10 & 0.10 & 0.10 & 0.10 & 0.10 \\
\hline Calcium propionate & 0.10 & 0.10 & 0.10 & 0.10 & 0.10 & 0.10 & 0.10 & 0.10 \\
\hline BHT $^{5}$ & 0.02 & 0.02 & 0.02 & 0.02 & 0.02 & 0.02 & 0.02 & 0.02 \\
\hline L-lysine & 0.04 & 0.06 & 0.09 & 0.11 & 0.04 & 0.06 & 0.09 & 0.11 \\
\hline L-Tryptophan & 0.12 & 0.08 & 0.04 & 0.00 & 0.12 & 0.08 & 0.04 & 0.00 \\
\hline Salt $(\mathrm{NaCl})$ & 0.25 & 0.25 & 0.25 & 0.25 & 0.25 & 0.25 & 0.25 & 0.25 \\
\hline Limestone & 0.06 & 0.04 & 0.02 & 0.00 & 0.06 & 0.04 & 0.02 & 0.00 \\
\hline Phytase & 0.00 & 0.00 & 0.00 & 0.00 & 0.30 & 0.30 & 0.30 & 0.30 \\
\hline \multirow[t]{2}{*}{ Total } & 100.00 & 100.00 & 100.00 & 100.00 & 100.00 & 100.00 & 100.00 & 100.00 \\
\hline & \multicolumn{7}{|c|}{ Nutrients $(\%)$} & \\
\hline Digestible Protein & 29.00 & 29.00 & 29.00 & 29.00 & 29.00 & 29.00 & 29.00 & 29.00 \\
\hline $\mathrm{DE}^{6}$ Kcal..kg-1 & 3400 & 3400 & 3400 & 3400 & 3400 & 3400 & 3400 & 3400 \\
\hline Calcium & 1.16 & 1.16 & 1.16 & 1.16 & 1.16 & 1.16 & 1.16 & 1.16 \\
\hline Available phosphorus & 0.63 & 0.64 & 0.64 & 0.65 & 0.63 & 0.64 & 0.64 & 0.65 \\
\hline Starch & 26.95 & 27.22 & 27.5 & 27.77 & 26.95 & 27.22 & 27.5 & 27.77 \\
\hline Total Lysine & 2.15 & 2.15 & 2.15 & 2.15 & 2.15 & 2.15 & 2.15 & 2.15 \\
\hline Methionine + Cystine & 1.46 & 1.46 & 1.46 & 1.46 & 1.46 & 1.46 & 1.46 & 1.46 \\
\hline Total Threonine & 1.73 & 1.73 & 1.73 & 1.73 & 1.73 & 1.73 & 1.73 & 1.73 \\
\hline \multirow[t]{2}{*}{ Total Tryptophan } & 0.50 & 0.50 & 0.50 & 0.50 & 0.50 & 0.50 & 0.50 & 0.50 \\
\hline & \multicolumn{7}{|c|}{ Chemical composition (Natural matter) $(\%)$} & \\
\hline Dry matter & 89.55 & 88.64 & 89.55 & 89.48 & 89.69 & 89.06 & 89.69 & 90.03 \\
\hline Gross Energy & 4091 & 4005 & 4010 & 4004 & 4054 & 4020 & 4027 & 4019 \\
\hline Crude protein ${ }^{5}$ & 38.98 & 37.38 & 36.96 & 37.92 & 35.86 & 36.53 & 36.92 & 36.57 \\
\hline Ethereal extract & 3.55 & 2.94 & 2.14 & 1.78 & 3.98 & 3.11 & 2.39 & 1.55 \\
\hline Mineral Matter & 11.77 & 12.82 & 10.29 & 10.78 & 12.09 & 10.62 & 10.49 & 10.18 \\
\hline
\end{tabular}

${ }^{1}$ Digestibility values as proposed by Signor et al. (2016). ${ }^{2}$ Digestibility values as proposed by Lewandowski et al. (2017). ${ }^{3}$ Mineral and vitamin supplementation: Guaranteed levels per kilogram of product: vit. A - 500.000 UI; vit. D3 - 250.000 UI; vit. E - 5.000 mg; vit. K3 - $500 \mathrm{mg}$; vit. B1 - $1.500 \mathrm{mg}$; vit. B2 - $1.500 \mathrm{mg}$; vit. B6 - $1.500 \mathrm{mg}$; vit. B12 - $4.000 \mathrm{mg}$; folic acid - $500 \mathrm{mg}$; calcium pantothenate - $4.000 \mathrm{mg}$; vit. C - $10.000 \mathrm{mg}$; biotin - $10 \mathrm{mg}$; inositol - 1.000; nicotinamide - 7.000; coline - $10.000 \mathrm{mg}$; cobalt - 10 mg; copper - $1.000 \mathrm{mg}$; iron - $5.000 \mathrm{mg}$; iodine - $200 \mathrm{mg}$; manganese - $1500 \mathrm{mg}$; selenium - $30 \mathrm{mg}$; and zinc - $9.000 \mathrm{mg} .{ }^{4} \mathrm{Values}$ suggested by Reis et al. (2011). ${ }^{5}$ Butyl hydroxy toluene. ${ }^{6}$ Digestive energy: Crude protein and digestible energy values established based on the minimum proposed by Freitas et al. (2011) for Rhamdia voulezi. ${ }^{7}$ Absent. ${ }^{8}$ Present.

\section{Mineral analysis}

Mineral analysis in bones was performed in three fish from each experimental unit. Fish were euthanized and kept in warm water $\left(80^{\circ} \mathrm{C}\right)$ for two minutes. Vertebrae were removed with tweezers, washed with distilled water, dried in an oven $\left(105^{\circ} \mathrm{C}\right)$ for 12 hours, and ground in a micro mill according to the methodology described by Furuya et al. (2001). A nitro-perchloric acid digestion was performed to extract calcium, copper, phosphorus, magnesium, manganese, and zinc from bones. Analysis was by Flame Absorption Spectrometry (FAAS).

\section{Intestinal histology}

The histomorphometry of intestinal villi was conducted according to the methodology proposed by Mello et al. (2013) in which transverse portions, 
approximately $5 \mathrm{~cm}$ long, were collected from the midgut. Samples were subsequently fixed in Alfac solution for six hours and preserved in $70 \%$ alcohol to remove the fixative until further processing. Histological tissues were dehydrated in an ascending ethanol series, clarified in xylol, and embedded in paraffin. Serial $5-\mu$ m-thick sections were stained with Hematoxylin-Eosin (HE) (Bancroft and Stevens, 1982) and PAS (Schiff periodic acid + alcian blue $(\mathrm{AB})$ in $\mathrm{pH} 2.5$ (Bancroft and Gamble, 2002). Images were captured through a 10X objective photomicroscope with the aid of the CellSens Standard 1.15® software. Fifteen villi were analyzed per fish; measurements of villi height (distance from the villi's apex to the end of the serosa), total villi height (distance from the villi's apex to the beginning of the muscular layer), and goblet cells count were obtained, a total of 135 measurements per treatment.

\section{Water quality}

Temperature, dissolved oxygen, and $\mathrm{pH}$ of water used in this study were $26.9 \pm 0.10^{\circ} \mathrm{C}, 6.39 \pm$ $0.37 \mathrm{mg} . \mathrm{L}^{-1}$, and $7.02 \pm 0.03$ respectively. Temperature was measured daily with a digital thermometer, and the other parameters were measured weekly through a multiparameter meter, model YSI 556. These values are within the conditions recommended by Gomes et al. (2000)

for the cultivation of Rhamdia quelen.

\section{Statistical analyses}

Data obtained were analyzed for normality, homoscedasticity and factorial variance analysis at a significance level of $5 \%$ to evaluate differences in the interaction between corn and wheat middling, replacement of corn by wheat middling, and phytase supplementation. The means' test was performed only for significant interactions, excluding isolated effects. The Tukey's test was used when differences were observed $(p<0.05)$ to compare means with the aid of the Statistica 7.0 software.

\section{Results}

Zootechnical performance

Weight gain (WG), apparent feed conversion (AFC), specific growth rate (SGR), protein efficiency rate (PER), hepatosomatic index (HI), and survival (SUR) were not affected by presence or absence of phytase $(\mathrm{P}>0.05)$ (Table 2). The visceral-somatic fat index (VSFI) presented differences only in the substitution of corn per wheat middling $(\mathrm{P}<0.05)$ (Table 2). The $100 \%$ substitution level showed the lowest VSFI values compared to the results in fish fed with 0,33 , and $67 \%$ wheat middling (Table 2).

Table 2. Zootechnical performance of Rhamdia quelen silver catfish juveniles fed diets containing increasing levels of wheat middling in substitution of corn, supplemented with phytase.

\begin{tabular}{|c|c|c|c|c|c|c|c|c|}
\hline \multirow[t]{2}{*}{ Variables* } & \multirow[t]{2}{*}{ Phytase } & \multicolumn{4}{|c|}{ Wheat middling (\%) } & \multicolumn{3}{|c|}{$\begin{array}{c}\text { Probability } \\
\text { (p-value })\end{array}$} \\
\hline & & $\mathbf{0}$ & 33 & 67 & 100 & $\mathbf{P Y}^{10}$ & $F^{11}$ & $\mathbf{I}^{12}$ \\
\hline \multirow{2}{*}{$\mathrm{WG}^{1}(\mathrm{~g})$} & $\mathrm{A}^{8}$ & $28.10 \pm 3.41$ & $22.04 \pm 0.94$ & $25.16 \pm 5.02$ & $21.12 \pm 2.89$ & \multirow{2}{*}{ Ns } & \multirow{2}{*}{ Ns } & \multirow{2}{*}{ Ns } \\
\hline & $\mathrm{P}^{9}$ & $29.78 \pm 4.47$ & $21.65 \pm 3.19$ & $24.76 \pm 7.73$ & $31.96 \pm 7.26$ & & & \\
\hline \multirow{2}{*}{$\mathrm{AFC}^{2}$} & A & $1.32 \pm 0.60$ & $2.13 \pm 0.57$ & $2.31 \pm 1.10$ & $1.63 \pm 0.40$ & \multirow{2}{*}{ Ns } & \multirow{2}{*}{ Ns } & \multirow{2}{*}{ Ns } \\
\hline & $\mathrm{P}$ & $1.29 \pm 0.23$ & $2.37 \pm 0.52$ & $1.41 \pm 0.20$ & $1.55 \pm 0.16$ & & & \\
\hline \multirow{2}{*}{$\operatorname{SGR}^{3}(\%)$} & A & $2.47 \pm 0.11$ & $1.78 \pm 0.67$ & $2.30 \pm 0.18$ & $2.07 \pm 0.37$ & \multirow{2}{*}{ Ns } & \multirow{2}{*}{ Ns } & \multirow{2}{*}{ Ns } \\
\hline & $\mathrm{P}$ & $2.55 \pm 0.18$ & $2.10 \pm 0.10$ & $2.25 \pm 0.51$ & $2.29 \pm 0.10$ & & & \\
\hline \multirow{2}{*}{$\operatorname{PER}^{4}(\%)$} & A & $1.38 \pm 0.17$ & $0.86 \pm 0.31$ & $1.23 \pm 0.25$ & $1.04 \pm 0.14$ & \multirow{2}{*}{ Ns } & \multirow{2}{*}{ Ns } & \multirow{2}{*}{ Ns } \\
\hline & $\mathrm{P}$ & $1.46 \pm 0.22$ & $1.11 \pm 0.11$ & $1.35 \pm 0.26$ & $1.51 \pm 0.39$ & & & \\
\hline \multirow{2}{*}{$\mathrm{HI}^{5}(\%)$} & A & $2.16 \pm 0.26$ & $1.73 \pm 0.07$ & $2.11 \pm 0.15$ & $2.11 \pm 0.43$ & \multirow{2}{*}{ Ns } & \multirow{2}{*}{ Ns } & \multirow{2}{*}{ Ns } \\
\hline & $\mathrm{P}$ & $1.95 \pm 0.21$ & $2.13 \pm 0.24$ & $2.01 \pm 0.46$ & $2.62 \pm 0.52$ & & & \\
\hline \multirow{2}{*}{$\operatorname{VSFI}^{6}(\%)$} & A & $0.94 \pm 0.07^{\mathrm{A}}$ & $1.47 \pm 0.53^{\mathrm{A}}$ & $1.04 \pm 0.35^{\mathrm{A}}$ & $0.54 \pm 0.16^{\mathrm{B}}$ & \multirow{2}{*}{ Ns } & \multirow{2}{*}{0.01} & \multirow{2}{*}{ Ns } \\
\hline & $\mathrm{P}$ & $1.55 \pm 0.26^{\mathrm{A}}$ & $1.20 \pm 0.45^{\mathrm{A}}$ & $1.05 \pm 0.10^{\mathrm{A}}$ & $0.47 \pm 0.13^{\mathrm{B}}$ & & & \\
\hline \multirow{2}{*}{$\operatorname{SUR}^{7}(\%)$} & A & $90.00 \pm 14.14$ & $56.67 \pm 36.82$ & $70.00 \pm 28.28$ & $83.33 \pm 12.47$ & \multirow{2}{*}{ Ns } & \multirow{2}{*}{ Ns } & \multirow{2}{*}{ Ns } \\
\hline & $\mathrm{P}$ & $100.00 \pm 0.00$ & $66.67 \pm 28.67$ & $86.67 \pm 4.71$ & $66.67 \pm 28.67$ & & & \\
\hline
\end{tabular}

*The Tukey's test was performed only for significant interactions. ${ }^{1}$ Weight gain; ${ }^{2}$ Apparent food conversion; ${ }^{3}$ Specific growth rate; ${ }^{4}$ Protein efficiency rate; ${ }^{5}$ Hepatosomatic index; ${ }^{6}$ Viscero-somatic fat index; ${ }^{7}$ Survival; ${ }^{8}$ Absent; ${ }^{9}$ Present; ${ }^{10}$ Phytase; ${ }^{11}$ Feed; ${ }^{12}$ Interaction. Values (mean \pm standard deviation) followed by different uppercase letters (A and B) on the same row represent statistical difference (P <0.05) between the levels of substitution of corn by wheat middling. Values (means \pm standard deviation) followed by lower case letters (a and b) in the same column represent statistical difference $(\mathrm{P}<0.05)$ between no phytase and phytase supplementation. Values (means \pm standard deviation) followed by distinct letters $(\mathrm{X}$ and $\mathrm{Y})$ represent statistical difference $(\mathrm{P}<0.05)$ in the interaction between factors. 
Analysis of the carcass chemical composition

The moisture did not show interactions between factors and in phytase supplementation ( $\mathrm{P}>0.05$ ), however, it presented differences in the substitution of corn by wheat middling $(\mathrm{P}<0.05)$. The highest values were evidenced at the $100 \%$ substitution level and the lowest values at the 0 and $67 \%$ substitution levels. The protein results did not show any interaction between factors $(\mathrm{P}>0.05)$, nor did it present differences in the corn substitution by wheat middling and phytase enzyme supplementation $(\mathrm{P}>0.05)$. The ethereal extract presented interaction between factors and differences in corn substitution by wheat middling $(\mathrm{P}<0.05)$; the level of $100 \%$ substitution with or without phytase showed the lowest values of ethereal extract in the carcass, and the $0 \%$ and $33 \%$ substitution levels, with and without or with phytase respectively, presented the highest levels of ethereal extract in the carcass. The mineral matter variable did not present differences in the interaction between factors, in the inclusion of wheat middling in the diets, and in the phytase supplementation $(\mathrm{P}>0.05)$ (Table 3$)$.

Table 3. The centesimal composition of the carcass of Rhamdia quelen silver catfish juveniles fed diets containing increasing levels of wheat middling in substitution to corn, supplemented with phytase.

\begin{tabular}{|c|c|c|c|c|c|c|c|c|}
\hline \multirow{2}{*}{ Variables* } & \multirow{2}{*}{ Phytase } & \multicolumn{4}{|c|}{ Levels of wheat middling inclusion (\%) } & \multicolumn{3}{|c|}{$\begin{array}{c}\text { Probability } \\
\text { (p-value })\end{array}$} \\
\hline & & $\mathbf{0}$ & 33 & 67 & 100 & $\mathbf{P Y}^{3}$ & $\mathbf{F}^{4}$ & $\mathbf{I}^{5}$ \\
\hline \multirow{2}{*}{ Moisture (\%) } & $\mathrm{A}^{1}$ & $75.64 \pm 0.45^{\mathrm{B}}$ & $75.53 \pm 0.61^{\mathrm{AB}}$ & $75.64 \pm 0.51^{\mathrm{B}}$ & $77.33 \pm 0.30^{\mathrm{A}}$ & \multirow[b]{2}{*}{ Ns } & \multirow{2}{*}{0.01} & \multirow{2}{*}{ Ns } \\
\hline & $\mathrm{P}^{2}$ & $75.59 \pm 0.51^{\mathrm{B}}$ & $76.36 \pm 0.34^{\mathrm{AB}}$ & $75.29 \pm 0.92^{\mathrm{B}}$ & $76.43 \pm 0.59^{\mathrm{A}}$ & & & \\
\hline \multirow{2}{*}{ Protein $(\%)$} & A & $17.15 \pm 0.58$ & $16.53 \pm 0.33$ & $16.71 \pm 0.01$ & $16.84 \pm 0.31$ & \multirow{2}{*}{ Ns } & \multirow{2}{*}{ Ns } & \multirow{2}{*}{ Ns } \\
\hline & $\mathrm{P}$ & $16.40 \pm 0.12$ & $16.45 \pm 0.24$ & $17.78 \pm 1.35$ & $15.79 \pm 0.61$ & & & \\
\hline \multirow{2}{*}{ Ethereal extract $(\%)$} & A & $6.04 \pm 0.38^{\mathrm{XY}}$ & $6.67 \pm 0.88^{X}$ & $5.75 \mathrm{~A} \pm 0.24^{\mathrm{XY}}$ & $4.43 \pm 0.62^{\mathrm{Y}}$ & \multirow{2}{*}{ Ns } & \multirow{2}{*}{0.01} & \multirow{2}{*}{0.03} \\
\hline & $\mathrm{P}$ & $6.29 \pm 0.60^{\mathrm{X}}$ & $6.20 \pm 0.22^{\mathrm{X}}$ & $5.28 \pm 0.83^{X Y}$ & $5.07 \pm 0.15^{\mathrm{Y}}$ & & & \\
\hline \multirow{2}{*}{ Mineral matter (\%) } & A & $3.29 \pm 0.25$ & $3.50 \pm 0.05$ & $3.22 \pm 0.05$ & $3.39 \pm 0.24$ & \multirow{2}{*}{ Ns } & \multirow{2}{*}{ Ns } & \multirow{2}{*}{ Ns } \\
\hline & $\mathrm{P}$ & $3.20 \pm 0.17$ & $3.09 \pm 0.08$ & $3.43 \pm 0.10$ & $3.55 \pm 0.04$ & & & \\
\hline
\end{tabular}

*The Tukey's test was performed only for significant interactions. ${ }^{1}$ Absent; ${ }^{2}$ Present; ${ }^{3}$ Phytase; ${ }^{4}$ Feed; ${ }^{5}$ Interaction.

Values (mean \pm standard deviation) followed by different uppercase letters (A and B) on the same row represent statistical difference $(\mathrm{P}<0.05)$ between the levels of substitution of corn by wheat middling. Values (means \pm standard deviation) followed by lower case letters $(\mathrm{a}$ and $\mathrm{b})$ in the same column represent statistical difference $(\mathrm{P}<0.05)$ between no phytase and phytase supplementation. Values (means \pm standard deviation) followed by distinct letters $(\mathrm{X}$ and $\mathrm{Y})$ represent statistical difference $(\mathrm{P}<0.05)$ in the interaction between factors.

\section{Mineral analysis}

For calcium (Ca), differences in the interaction between factors and differences in the levels of substitution of corn by wheat middling were observed $(\mathrm{P}<0.05)$; the highest values were observed in the 33 and $100 \%$ substitution levels without phytase, and 0.33 and $67 \%$ treatments with phytase. Manganese $(\mathrm{Mn})$ presented interaction between factors and differences in the corn substitution by wheat middling $(\mathrm{P}<0.05)$; the $33 \%$ substitution level without phytase presented the highest values for this mineral, and the 100\% substitution level with phytase presented the lowest values. Copper $(\mathrm{Cu})$, magnesium $(\mathrm{Mg})$, phosphorus (P), and zinc ( $\mathrm{Zn})$ presented no differences $(P>0.05)$ in the interaction between factors, corn substitution by wheat middling, and enzyme supplementation (Table 4).

\section{Intestinal histology}

The histomorphometry analysis of silver catfish intestines only showed interaction between factors in the variables of villi height and total villi height $(\mathrm{P}<0.05)$. In both variables, the level of $67 \%$ wheat middling substitution without phytase differed from the same level with phytase. The other levels did not differ. The number of goblet cells in the intestinal villi of silver catfish (Table 5) showed no differences considering interactions between factors, levels of substitution of corn by wheat middling, and the presence or absence of phytase $(\mathrm{P}>0.05)$.

\section{Discussion}

The phytase-containing diets did not provide an improvement in the zootechnical performance of silver catfish $(\mathrm{P}>0.05)$. Plant-based ingredients may present phytase endogenous activity, which, in turn, varies according to the ingredient. Wheat and derivatives have high endogenous phytase activity (Godoy et al., 2005; Steiner et al., 2007). This fact may explain the lack of positive effects on the productive performance of silver catfish from the diets supplemented with phytase in the present study. In contrast to these results, other studies suggest a minimum supplementation of 1,000 ; 
433.33; and 2,185 FTU/kg to obtain improved zootechnical responses in omnivorous species, such as Nile tilapia, pacu, and tambaqui, respectively, in diets containing plant ingredients (Liebert and Portz, 2005; Furuya et al., 2008; Mendonça et al., 2012). The addition of 1,500 FTU/kg in diets containing plant ingredients is recommended by Rocha et al. (2008) for improved zootechnical performance in Rhamdia quelen.
They speculate that the improvement in productive performance may be related to the positive effect of the enzyme on protein digestibility and availability of nutrients which, consequently, favors intestinal absorption. Diets used in the present study may have achieved protein and energy requirements for the species (Freitas et al., 2011), contributing to the lack of differences in fish performance.

Table 4. Bone mineral composition of Rhamdia quelen silver catfish juveniles fed diets containing increasing levels of wheat middling in substitution to corn, supplemented with phytase.

\begin{tabular}{|c|c|c|c|c|c|c|c|c|}
\hline \multirow[t]{2}{*}{ Variables* } & \multirow[t]{2}{*}{ Phytase } & \multicolumn{4}{|c|}{ Levels of wheat middling inclusion (\%) } & \multicolumn{3}{|c|}{$\begin{array}{c}\text { Probability } \\
(p \text {-value })\end{array}$} \\
\hline & & $\mathbf{0}$ & 33 & 67 & 100 & $\mathbf{P Y}^{9}$ & $\mathbf{F}^{10}$ & $\mathbf{I}^{11}$ \\
\hline \multirow{2}{*}{$\mathrm{Ca}(\mathrm{mg} / \mathrm{g})^{1}$} & $\mathrm{~A}^{7}$ & $84.86 \pm 8.83^{\mathrm{XY}}$ & $93.53 \pm 4.37^{\mathrm{X}}$ & $83.01 \pm 3.38^{X Y}$ & $88.22 \pm 1.80^{\mathrm{X}}$ & \multirow[b]{2}{*}{ Ns } & \multirow{2}{*}{0.009} & \multirow[b]{2}{*}{0.007} \\
\hline & $\mathrm{P}^{8}$ & $86.63 \pm 1.73^{\mathrm{X}}$ & $89.18 \pm 2.34^{\mathrm{X}}$ & $88.04 \pm 2.12^{\mathrm{X}}$ & $70.98 \pm 3.58^{Y}$ & & & \\
\hline \multirow{2}{*}{$\mathrm{Cu}(\mathrm{mg} / \mathrm{g})^{2}$} & A & $0.07 \pm 0.05$ & $0.07 \pm 0.08$ & $0.09 \pm 0.01$ & $0.09 \pm 0.04$ & \multirow{2}{*}{ Ns } & \multirow{2}{*}{ Ns } & \multirow{2}{*}{ Ns } \\
\hline & $\mathrm{P}$ & $0.09 \pm 0.02$ & $0.08 \pm 0.02$ & $0.10 \pm 0.07$ & $0.09 \pm 0.04$ & & & \\
\hline \multirow{2}{*}{$\mathrm{Mg}(\mathrm{mg} / \mathrm{g})^{3}$} & A & $0.69 \pm 0.22$ & $0.61 \pm 0.10$ & $0.84 \pm 0.08$ & $0.85 \pm 0.14$ & \multirow{2}{*}{ Ns } & \multirow{2}{*}{ Ns } & \multirow{2}{*}{ Ns } \\
\hline & $\mathrm{P}$ & $0.90 \pm 0.14$ & $0.83 \pm 0.11$ & $0.58 \pm 0.14$ & $0.81 \pm 0.04$ & & & \\
\hline \multirow{2}{*}{$\mathrm{Mn}(\mathrm{mg} / \mathrm{g})^{4}$} & A & $0.05 \pm 0.03^{X Y}$ & $0.09 \pm 0.01^{\mathrm{X}}$ & $0.04 \pm 0.02^{\mathrm{XY}}$ & $0.06 \pm 0.01^{\mathrm{XY}}$ & \multirow{2}{*}{ Ns } & \multirow{2}{*}{0.04} & \multirow{2}{*}{0.03} \\
\hline & $\mathrm{P}$ & $0.06 \pm 0.01^{\mathrm{XY}}$ & $0.07 \pm 0.01^{\mathrm{XY}}$ & $0.08 \pm 0.02^{\mathrm{XY}}$ & $0.03 \pm 0.01^{\mathrm{Y}}$ & & & \\
\hline \multirow{2}{*}{$\mathrm{P}(\mathrm{mg} / \mathrm{g})^{5}$} & A & $107.05 \pm 7.46$ & $106.66 \pm 16.18$ & $100.33 \pm 14.41$ & $95.85 \pm 1.40$ & \multirow{2}{*}{ Ns } & \multirow{2}{*}{ Ns } & \multirow{2}{*}{ Ns } \\
\hline & $\mathrm{P}$ & $98.48 \pm 1.32$ & $92.71 \pm 3.57$ & $100.04 \pm 8.89$ & $90.36 \pm 1.46$ & & & \\
\hline \multirow{2}{*}{$\mathrm{Zn}(\mathrm{mg} / \mathrm{g})^{6}$} & A & $0.04 \pm 0.02$ & $0.06 \pm 0.01$ & $0.03 \pm 0.02$ & $0.04 \pm 0.02$ & \multirow{2}{*}{ Ns } & \multirow{2}{*}{ Ns } & \multirow{2}{*}{ Ns } \\
\hline & $\mathrm{P}$ & $0.03 \pm 0.01$ & $0.05 \pm 0.02$ & $0.04 \pm 0.01$ & $0.02 \pm 0.01$ & & & \\
\hline
\end{tabular}

*The Tukey's test was performed only for significant interactions. ${ }^{1}$ Calcium; ${ }^{2}$ Copper; ${ }^{3}$ Magnesium; ${ }^{4}$ Manganese; ${ }^{5}$ Phosphorus; ${ }^{6} \mathrm{Zinc} ;{ }^{7} \mathrm{Absent} ;{ }^{8} \mathrm{Present} ;{ }^{9} \mathrm{Phytase} ;{ }^{10} \mathrm{Feed} ;{ }^{11}$ Interaction. Values (mean \pm standard deviation) followed by different uppercase letters (A and $\mathrm{B}$ ) on the same row represent statistical difference $(\mathrm{P}<0.05)$ between the levels of substitution of corn by wheat middling. Values (means \pm standard deviation) followed by lower case letters ( $a$ and $b$ ) in the same column represent statistical difference (P $<0.05$ ) between no phytase and phytase supplementation. Values (means \pm standard deviation) followed by distinct letters $(\mathrm{X}$ and $\mathrm{Y})$ represent statistical difference $(\mathrm{P}<0.05)$ in the interaction between factors.

Table 5. Histomorphometry of the intestine of Rhamdia quelen silver catfish juveniles fed diets with increasing levels of substitution of corn by wheat middling, supplemented with phytase.

\begin{tabular}{|c|c|c|c|c|c|c|c|c|}
\hline \multirow[t]{2}{*}{ Variables* } & \multirow{2}{*}{ Phytase } & \multicolumn{4}{|c|}{ Levels of wheat middling inclusion (\%) } & \multicolumn{3}{|c|}{$\begin{array}{c}\text { Probability } \\
\text { (p-value) }\end{array}$} \\
\hline & & 0 & 33 & 67 & 100 & $\mathbf{P Y}^{3}$ & $\mathbf{F}^{4}$ & $I^{5}$ \\
\hline \multirow[b]{2}{*}{$\mathrm{VH}^{6}(\mu \mathrm{m})$} & $\mathrm{A}^{1}$ & $\begin{array}{c}378.23 \pm 56.75 \\
X Y\end{array}$ & $\begin{array}{c}377.24 \pm 68.80 \\
X Y\end{array}$ & $\underset{Y}{226.68 \pm 36.11}$ & $\begin{array}{c}362.70 \pm 38.53 \\
X Y\end{array}$ & \multirow[b]{2}{*}{ Ns } & \multirow[b]{2}{*}{ Ns } & \multirow[b]{2}{*}{0.02} \\
\hline & $\mathrm{P}^{2}$ & $\begin{array}{c}379.58 \pm 26.87 \\
X Y\end{array}$ & $\begin{array}{c}342.54 \pm 40.90 \\
X Y\end{array}$ & $\begin{array}{c}391.54 \pm 28.69 \\
x\end{array}$ & $\begin{array}{c}343.61 \pm 54.13 \\
X Y\end{array}$ & & & \\
\hline \multirow[b]{2}{*}{$\mathrm{TVH}^{7}(\mu \mathrm{m})$} & A & $471.3 \pm 69.20^{\mathrm{XY}}$ & $\underset{X Y}{456.68 \pm 76.83}$ & $\begin{array}{c}302.09 \pm 28.22 \\
\mathrm{Y}\end{array}$ & $\underset{X Y}{449.20 \pm 39.59}$ & \multirow[b]{2}{*}{ Ns } & \multirow[b]{2}{*}{ Ns } & \multirow[b]{2}{*}{0.03} \\
\hline & $\mathrm{P}$ & $\underset{\mathrm{XY}}{479.38 \pm 41.65}$ & $\begin{array}{c}432.45 \pm 43.24 \\
\mathrm{XY}\end{array}$ & $\begin{array}{c}496.34 \pm 46.70 \\
x\end{array}$ & $\underset{\mathrm{XY}}{438.64 \pm 70.66}$ & & & \\
\hline $\mathrm{GC}^{8}$ & $\begin{array}{l}\mathrm{A} \\
\mathrm{P}\end{array}$ & $\begin{array}{c}52.89 \pm 11.13 \\
41.48 \pm 2.38\end{array}$ & $\begin{array}{l}51.5 \pm 6.01 \\
44.4 \pm 0.77\end{array}$ & $\begin{array}{c}35.99 \pm 3.74 \\
58.59 \pm 25.46\end{array}$ & $\begin{array}{l}47.78 \pm 11.88 \\
48.33 \pm 10.14\end{array}$ & Ns & Ns & Ns \\
\hline
\end{tabular}

*The Tukey's test was performed only for significant interactions. ${ }^{1}$ Absent; ${ }^{2}$ Present; ${ }^{3}$ Phytase; ${ }^{4}$ Feed; ${ }^{5}$ Interaction; ${ }^{6}$ Villi height; ${ }^{7}$ Total villi height; ${ }^{8}$ Number of goblet cells present in the villi. Values (mean \pm standard deviation) followed by different uppercase letters (A and B) on the same row represent statistical difference $(\mathrm{P}<0.05)$ between the levels of substitution of corn by wheat middling. Values (means \pm standard deviation) followed by lower case letters ( $a$ and $b$ ) in the same column represent statistical difference $(\mathrm{P}<0.05)$ between no phytase and phytase supplementation. Values (means \pm standard deviation) followed by distinct letters $(\mathrm{X}$ and $\mathrm{Y})$ represent statistical difference $(\mathrm{P}<0.05)$ in the interaction between factors.

The higher deposition of visceral and body fat observed in fish fed diets with 0,33 , and $67 \%$ of corn substitution by wheat middling can be explained by the fact that these diets required an increased supplementation of soybean oil to complement their energy content. Erfanullah (1998) states that diets containing high lipid levels may increase visceral and body fat content. Moro 
et al. (2010) found that an increase in the carbohydrate:lipid ratio leads to low lipid deposition in silver catfish (Rhamdia quelen) but does not interfere with growth or feed conversion. In the same study, fish fed diets containing low carbohydrate:lipid ratios presented increased deposition of visceral and body fat. This fact occurs because the energetic sources of lipids present improved absorption and conversion in somatic lipids (Glencross, 2009).

Another factor that may have contributed to this result in silver catfish is that corn has less available phosphorus in its composition than wheat middling in diets supplemented with phytase $(0.20$ x $0.39 \%$, respectively) (Signor et al., 2016; Lewandowski et al., 2017); in addition, it is known that phosphorus acts on the $\beta$-oxidation of fatty acids. Therefore, the use of wheat middling instead of corn can be carried out without impairing growth performance and reducing corporal and visceral lipid content in silver catfish.

The availability of nutrients in diets with plant ingredients may be compromised by the chelating power of phytate because it has the ability to bind minerals and other nutrients (Vohra and Satyanarayan, 2002). The chelation of phytate with minerals appears to have been minimized in this study because no differences between treatments were observed in the carcass mineral matter. The values observed in this study are similar to those reported by Rocha et al. (2008), Goes et al. (2015) and Rabelo et al. (2016) for silver catfish.

The fish fed the diet containing 100\% corn replacement by wheat middling and supplementation of phytase presented the lowest values of calcium in the bone composition. The fact that phosphorus and calcium compete for the same absorption site because they have similar physical and chemical properties may explain this low calcium deposition level since excess phosphorus impairs calcium absorption and bone mineralization (Buzinaro et al., 2006). The increase in phosphorus availability was probably provided by the action of phytase on phytate, which lowered the manganese deposition in the bones of fish fed diets containing $100 \%$ replacement of corn by wheat middling and phytase supplementation. This result corroborates those reported by Satoh et al. (1992), who state that increasing dietary phosphorus availability reduces the bone mineralization of manganese in the common carp (Cyprinus carpio).
Phytase supplementation did not influence the phosphorus deposition in silver catfish bones when compared to the diets that did not contain the enzyme. The higher availability of phosphorus provided by the action of phytase was possibly directed to lipid metabolism because fish fed diets with the enzyme presented lower lipid deposition in the carcass and lower fat content in the viscera compared to fish fed diets without phytase. Rocha et al. (2008) observed that silver catfish fed diets containing phytase showed low deposition of body and visceral lipids. This result may be related to the fact that phosphorus acts on the $\beta$-oxidation of fatty acids, contributing to a low lipid deposition in fish (Eya and Lovell, 1997).

The presence of phytase in the diets did not influence the deposition of magnesium in the bones of silver catfish. Lewandowski et al. (2017) showed that phytase did not increase the digestibility of magnesium in silver catfish. Our results are in agreement with those reported by Satoh et al. (1992) about the lack of phosphorus influence on magnesium levels in the bones of the common carp (C. carpio).

Wheat middling contains more copper than corn (21.8 x 2.9 mg. $\mathrm{kg}^{-1}$, respectively) (Rostagno et al., 2011). Because this mineral has a high phytate chelating capacity (Vohra et al., 1965), fish fed diets with wheat middling and supplemented with phytase present a better copper absorption than those fed diets without enzyme supplementation (Lewandowski et al., 2017). However, this increased copper absorption by silver catfish was not used for the deposition of this mineral in the bones because, in the present study, no differences were observed on the deposition of this mineral between diets. Possibly, the contribution of copper provided by the enzyme supplementation in the diets was directed to the metabolism of other nutrients and constituents of other enzymes (NRC, 1993). Ferrari et al. (2004) also did not find differences in the copper deposition in bones of Nile tilapia, even in diets containing high dosages of copper $\left(320 \mathrm{mg} \cdot \mathrm{kg}^{-1}\right)$. These authors also claim copper is preferentially deposited in the liver and that high dosages of copper can cause liver alterations such as excessive enlargement, blemishes, and opaque staining. Nevertheless, in this study, no differences were observed in the hepatosomatic index of fish fed the different diets.

Intestinal villi have the function of absorbing nutrients; however, their activity may be hindered 
in the presence of anti-nutritional factors. Among them, phytate is one of the most studied in animal nutrition due to its effects on the availability of some minerals and proteins in the intestine (Selle et al., 2009). In the present study, the 67\% substitution level of corn by wheat middling without phytase supplementation presented the lowest values of villi height and total villi height $(\mathrm{P}<0.05)$. However, it can be said that these alterations were not caused by the diets offered to the fish because the number of goblet cells did not present differences between treatments $(\mathrm{P}>0.05)$. The differentiation of these cells is indicative of histological alterations (Schwarz et al., 2010), indicating that the presence of phytate in wheat middling did not lead to histological alterations in the intestines of silver catfish.

Goblet cells are involved in mucus production and secretion of glycoproteins to protect the intestinal epithelium against intestinal pathogens; they are more active or in larger numbers when pathogens are present than when they are absent (Schwarz et al., 2010). Fish fed different diets presented no differences in the number of goblet cells $(\mathrm{P}>0.05)$, suggesting that the level of phytic acid present in corn and wheat middling were not enough to alter the number of these cells during the experimental phase.

\section{Conclusion}

It is concluded that wheat middling can completely substitute corn in diets for Rhamdia quelen silver catfish juveniles. The inclusion of phytase $(1,500 \mathrm{FTU} / \mathrm{kg})$ did not nutritionally favor the studied diets.

\section{Conflict of interest}

The authors declare that there is no conflict of interest.

\section{Ethics Committee}

The experimental procedures used in the study were approved by the Animal Use Ethics Committee (AUEC) of the Universidade Estadual do Oeste do Paraná - UNIOESTE, under protocol number 51/16.

\section{References}

AOAC - Association of Official Analytical Chemists. Official methods of analysis of the Association Analytical Chemists. $18^{\text {th }}$ ed. Gaithersburg: Maryland. 2000.
Bancroft, J.D.; Stevens, A. Theory and practice of histological methods. $2^{\text {nd }}$ ed. New York: Churchill Livingstone. 1982. 662p.

Bancroft, J.D.; Gramble, M. Theory and practice of histological techniques. New York: Churchill Livingstone. 2002. 796p.

Buzinaro, E.F.; Almeida, R.N.; Mazeto, G.M.F.D.S. Biodisponibilidade do cálcio dietético. Arquivos Brasileiros de Endocrinologia \& Metabologia, 50(5): 852861, 2006.

Eya, J.C.; Lovell, R.T. Available phosphorus requirements of food-size channel catfish (Ictalurus punctatus) fed practical diets in ponds. Aquaculture, 154(3-4): 283-291, 1997.

Erfanullah, A.K.J. Effect of dietary carbohydrateto-lipid ratio on growth and body composition of walking catfish (Clarias batrachus). Aquaculture, 161(1-4): 159-168, 1998.

Francis, G.; Makkar, H.P.; Becker, K. Antinutritional factors present in plantderived alternate fish feed ingredients and their effects in fish. Aquaculture, 199(3-4): 197-227, 2001.

Ferrari, J.E.C.; Barros, M.M.; Pezzato, L.E., Gonçalves, G.S.; Hisano, H.; Kleemann, G.K. Níveis de cobre em dietas para a tilápia do Nilo, Oreochromis niloticus. Acta Scientiarum: Animal Sciences, 26(4): 429436, 2004.

Freitas, J.M.A.; Sary, C.; Luchesi, J.D.; Feiden, A.; Boscolo, W.R. Proteína e energia na dieta de jundiás criados em tanques-rede. Revista Brasileira de Zootecnia, 40(12): 2628-2633, 2011.

Furuya, W.M.; Gonçalves, G.S.; Furuya, V.R.B.; Hayashi, C. Fitase na alimentação da Tilápia do Nilo (Oreochromis niloticus). Desempenho e digestibilidade. Revista Brasileira de Zootecnia, 30(3): 924-929, 2001.

Furuya, W.M.; Michelato, M.; Silva, L.C.R.; Santos, L.D.; Silva, T.S.C.; Schamber, C.R.; Furuya, V.R.B. Fitase em rações para juvenis de pacu (Piaractus mesopotamicus). Boletim do Instituto de Pesca, 34(4): 489-496, 2008.

Glencross, B.D. Exploring the nutritional demand for essential fatty acids by aquaculture species. Reviews in Aquaculture, 1(2): 71124, 2009.

Godoy, S.; Chicco, C.; Meschy, F.; Requena, F. Phytic phosphorus and phytase activity of 
animal feed ingredients. Interciencia, 30(1): 24-28, 2005.

Goes, E.S.R.; Feiden, A.; Neu, D.H.; Boscolo, W.R.; Signor, A. Rendimentos do processamento e composição centesimal de filés do jundiá Rhamdia voulezi. Ciência Animal Brasileira, 16(4): 481-490, 2015.

Gomes, L.C.; Chippari-Gomes, A.R.; Lopes, N.P.; Araujo-Lima, C.A.R.M. Efficacy of benzocaine as an anesthetic in juvenil tambaqui Colossoma macropolum. Journal of the World Aquaculture Society, 32(4): 426-431, 2001.

Gomes, L.C.; Golombieski, J.I.; Gomes, A.R.C.; Baldisserotto, B. Biologia do jundiá Rhamdia quelen (Teleostei, pimelodidae). Ciência Rural, 30(1): 179-185, 2000.

Graf, E.; Eaton, J.W. Antioxidant functions of phytic acid. Free Radical Biology and Medicine, 8(1), 61-69, 1990.

Hilton, J.W.; Slinger, S.J. Effect of wheat bran replacement of wheat middlings in extrusion processed (floating) diets on the growth of juvenile rainbow trout (Salmo gairdneri). Aquaculture, 35: 201-210, 1983.

Hughes, S.G. Use of triticale as a replacement for wheat middlings in diets for Atlantic salmon. Aquaculture, 90(2): 173-178, 1990.

Kumar, V.; Sinha, A.K.; Makkar, H.P.S.; Boeck, G.; Becker, K. Phytate and phytase in fish nutrition. Journal of Animal Physiology and Animal Nutrition, 96(3): 335-64, 2012.

Lewandowski, V.; Feiden, A.; Signor, A.; Bittencourt, F.; Moro, E.B.; Pessini, J.E.; Boscolo, W.R. Digestibility of vegetal energetic ingredients supplemented with phytase for silver catfish (Rhamdia voulezi). Aquaculture, 467: 71-75, 2017.

Lelis, G.R.; Fernando, L.; Albino, T.; Rodrigues, C.; Rostagno, H.S.; Gomes, P.C.; Borsatto, C.G. Suplementação dietética de fitase sobre o metabolismo de nutrientes de frangos de corte. Revista Brasileira de Zootecnia, 39(8): 1768-1773, 2010.

Lieber T.F.; Portz, L. Nutrient utilization of Nile tilapia Oreochromis niloticus fed plant based low phosphorus diets supplemented with graded levels of different sources of microbial phytase. Aquaculture, 248(1-4): 111-119, 2005.

Mello, H.M.; Julieta, R.E.; Niza, I.G.; Moraes, F.R.; Ozório, R.O.A.; Shimada, M.; Engracia, F.J.R.; Claudiano, G.S. Efeitos benéficos de probióticos no intestino de juvenis de Tilápiado-Nilo. Pesquisa Veterinária Brasileira, 33(6): 724-730, 2013.

Mendonça, P.P.; Costa, P.C.; Polese, M.F.; Vidal, J.M.V.; Andrade, D.R. Efeito da suplementação de fitase na alimentação de juvenis de tambaqui (Colossoma macropomum). Archivos de Zootecnia, 61(235): 437-448, 2012

Moro, G.V.; Camilo, R.Y.; Moraes, G.; Fracalossi, D.M. Dietary non-protein energy sources: growth, digestive enzyme activities and nutrient utilization by the catfish jundiá. Aquaculture Research, 41(3): 394-400, 2010.

Moutinho, S.; Martínez-Llorens, S.; Tomas-Vidal, A.; Jover-Cerda, M.; Oliva-Teles, A.; Peres, $\mathrm{H}$. Meat and bone meal as partial replacement for fish meal in diets for gilthead seabream (Sparus aurata) juveniles: Growth, feed efficiency, amino acid utilization, and economic efficiency. Aquaculture, 468(1): 271-277, 2017.

NRC-National Research Council. Nutrient Requirements of Fish. Washington: National Academy Press, 1993.124p.

Pedron, F.A.; Neto, J.R.; Emanuelli, T.; Silva, L.P.; Lazzari, R.; Corrêia, V.; Bergamin, G.T.; Veiverberg, C.A. Cultivo de jundiás alimentados com dietas com casca de soja ou de algodão. Pesquisa agropecuária brasileira, 43(1): 93-98, 2008.

Rabelo, P.C.; Pessini, J.E.; Sanchez, M.S.D.S.; Boscolo, W.R.; Feiden, A.; Bittencourt, F.; Signor, A. Sorghum in diets for silver catfish Rhamdia quelen. Acta Veterinaria Brasilica, 10(4): 339-345, 2016.

Rocha, C.B.; Pouey, J.L.O.F.; Enke, D.B.S.; Xavier, E.G.; Almeida, D.B. Suplementação de fitase microbiana na dieta de alevinos de jundiá: efeito sobre o desempenho produtivo e as características de carcaça. Ciência Rural, 37(6): 1772-1778, 2008.

Rostagno, H.S.; Albino, L.F.T.; Donzele, J.L.; Gomes, P.C.; De Oliveira, R.F.; Lopes, D.C.; Ferreira, A.S.; Barreto, S.L.T.; Euclides, R.F. Tabelas brasileiras para suínos e aves: composição de alimentos exigências nutricionais. $3^{\mathrm{a}}$ ed. Viçosa: Universidade Federal de Viçosa, 2011. 186p.

Satoh, S.; Izume, K.; Takeuchi, T. Effect of supplemental tricalcium phosphate on zinc and manganese availability to common carp. 
Nippon Suisan Gakkaishi, 58(3): 539-545, 1992.

Schwarz, K.K.; Furuya, W.M.; Natali, M.R.M.; Michelato, M.; Gualdezi, M.C. Mananoligossacarídeo em dietas para juvenis de tilápias do Nilo. Acta Scientiarum: Animal Sciences, 32(2): 197-203, 2010.

Selle, P.H.; Ravindran, V.; Partridge, G.G. Beneficial effects of xylanase and/or phytase inclusions on ileal amino acid digestibility, energy utilisation, mineral retention and growth performance in wheat-based broiler diets. Animal Feed Science and Technology, 153(3-4): 303-313, 2009.

Signor, A.A.; Boscolo, W.R.; Feiden, A.; Signor, A. Triguilho na alimentação da tilápia do nilo (Oreochromis niloticus L.): digestibilidade e desempenho. Ciência Rural, 37(4): 11161121, 2007.

Signor, A.; Lewandowski, V.; Silva, R.A.D.; Fries, E.M.; Schuller, J.M. Effect of phytase on digestibility of corn, sorghum and wheat bran by silver catfish (Rhamdia voulezi). Acta Scientiarum: Animal Sciences, 38(4): 355359, 2016.

Steiner, T.; Mosenthin, R.; Zimmermann, B.; Greiner, R.; Roth, S. Distribution of phytase activity, total phosphorus and phytate phosphorus in legume seeds, cereals and cereal by-products as influenced by harvest year and cultivar. Animal Feed Science and Technology, 133(3-4): 320-334, 2007.

Vohra, A.; Satyanarayana, T. Purification and characterisation of a thermostable and acidstable phytase from Pichia anomala. World Journal of Microbiology and Biotechnology, 18(7): 687-691, 2002.

Vohra, P.; Gray, A.; Kratzer, F.H. Phytic acidmetal complexes. Experimental Biology and Medicine, 120(2), 447-449, 1965. 